\title{
Implementasi Metode Backpropagation Neural Network (BNN) dalam Sistem Klasifikasi Ketepatan Waktu Kelulusan Mahasiswa (Studi Kasus: Program Studi Sistem Informasi Universitas Jember)
}

(Implementation of Backpropagation Neural Network (BNN)

Method in Classification System of Timeliness of Graduation Students

(Case Study: Information System Study Program of Jember University))

\author{
Fadhel Akhmad Hizham, Yanuar Nurdiansyah, Diksy Media Firmansyah \\ Program Studi Sistem Informasi, Fakultas Ilmu Komputer, Universitas Jember (UNEJ) \\ Jln. Kalimantan 37, Jember 68121 \\ E-mail: hizhamfadhel@gmail.com
}

\begin{abstract}
Abstrak
Program Studi Sistem Informasi adalah salah satu program studi di Universitas Jember yang berdiri sejak tahun 2009. Sampai saat ini sudah cukup banyak mahasiswa yang telah menyandang gelar sarjana, khususnya angkatan 2009-2013, namun tidak banyak yang berhasil menyelesaikan studinya tepat waktu sehingga berdampak pada penilaian akreditasi dari program studi tersebut. Mahasiswa memiliki beban pembelajaran sekurang-kurangnya 144 SKS dengan masa studi selama 45 tahun untuk memperoleh gelar sarjana. Berdasarkan permasalahan tersebut, terdapat berbagai cara untuk mengklasifikasi ketepatan waktu kelulusan mahasiswa, salah satunya dengan metode jaringan syaraf tiruan Backpropagation. Data yang digunakan yaitu data lulusan mahasiswa Program Studi Sistem Informasi Universitas Jember angkatan tahun 2011-2013. Atribut yang digunakan untuk klasifikasi berjumlah 9 atribut, yaitu nilai Indeks Prestasi (IP) semester 1 sampai 6, jumlah SKS yang ditempuh, semester saat terakhir kali memprogram matakuliah Kuliah Kerja Nyata (KKN) dan Praktik Kerja Lapang (PKL). Kelas yang digunakan untuk klasifikasi yaitu ketepatan waktu lulus mahasiswa tersebut. Penentuan ketepatan waktunya yaitu jika masa studi kurang dari sama dengan 60 bulan, maka mahasiswa tersebut lulus tepat waktu dan jika lebih dari 60 bulan maka tidak tepat waktu. Penerapan metode klasifikasi ini dilakukan dengan menggunakan learning rate 0.1, $0.3,0.5,0.7$, dan 0.9 dengan batas iterasi masing-masing 1.000, 2.000, dan 3.000 iterasi. Nilai akurasi tertinggi yaitu sebesar 98,82\% pada iterasi ke-2000 dan 3000, masing-masing dengan learning rate = 0,7 dan 0,9 untuk iterasi ke-2000 dan learning rate $=0,5,0,7$ dan 0,9 untuk iterasi ke-3000. Hasil tersebut didapat dari jumlah data benar sebanyak 167 data dari 169 data secara keseluruhan.
\end{abstract}

Kata Kunci: Data Mining, Klasifikasi, Jaringan Syaraf Tiruan, Metode Backpropagation Neural Network.

\section{Abstract}

Information System Studies Program is one of the courses at the University of Jember which has established since 2009.Now there are a lot of students who have earned a bachelor degree especially class of 2009-2013, but not many students who succeeded ther study on time. Students have a learning load of at least 144 credits with a study period of 4-5 years to gain bachelor degree. Based on these problems, there are various ways to classify the timeliness of graduation students, one of them artificial neural network method Backpropagation. The data used is the data of graduates of students of Information System Study Program of Universitas Jember year 2011-2013. Attributes used for the classification amounted to 9 attributes, namely the value of Achievement Index (AI) semester 1 to 6, the number of credits taken, the last semester when programmed the course of Real Work Lecture (RWL) and Field Work Practice (FWP). Classes used for the classification is the timeliness of graduating students. Determination of the accuracy of time is if the study period is less than equal to 60 months, then the student graduated on time and if more than 60 months then not on time. The application of this classification method is done by using learning rate 0.1, 0.3, 0.5, 0.7, and 0.9 with the iteration limit of 1,000, 2,000, and 3,000 iterations respectively. The highest accuracy was $98.82 \%$ for the 2000 and 3000 iterations, each with learning rate $=$ 0.7 and 0.9 for the 2000th iteration and learning rate =0.5, 0.7 and 0, 9 for the 3000th iteration. The results obtained from the correct amount of data as much as 167 data from 169 data as a whole.

Keywords: Data Mining, Classification, Artificial Neural Network, Backpropagation Neural Network Method.

\section{PENDAHULUAN}

Konsep data mining adalah konsep eksplorasi dan analisis data yang jumlahnya banyak untuk menemukan pola-pola tersembunyi di data tersebut. Konsep ini sering digunakan oleh peneliti untuk menganalisis suatu informasi. Salah satu konsep data mining yang sering digunakan sebagai langkah awal dalam pengambilan keputusan adalah klasifikasi. Klasifikasi dalam data mining sering digunakan untuk menemukan model yang menggambarkan dan membedakan kelas yang bertujuan untuk menperkirakan kelas dari objek yang belum diketahui label kelasnya (Han \& Kamber, 2006).

Program Studi Sistem Informasi adalah salah satu program studi di Universitas Jember yang berdiri sejak 
tahun 2009. Saat ini banyak mahasiswa yang telah menyandang gelar sarjana khususnya angkatan 2009-2013, namun tidak banyak yang berhasil menyelesaikan studinya tepat waktu. Mahasiswa memiliki beban pembelajaran sekurang-kurangnya 144 SKS dengan masa studi selama 45 tahun untuk memperoleh gelar sarjana (UNEJ, 2015). Oleh karena itu, mahasiswa dinyatakana lulus tepat waktu jika masa studinya kurang dari atau sama dengan 5 tahun (60 bulan).

Berdasarkan permasalahan tersebut, terdapat berbagai cara untuk membuat kebijakan agar dapat meningkatkan data prosentase antara tepat waktu dan tidak tepat waktu. Klasifikasi tersebut menggunakan prinsip data mining, khususnya dengan metode klasifikasi Nä̈ve Bayes.

Penelitian dengan judul "Data Mining Menggunakan Algoritma Naïve Bayes Untuk Klasifikasi Kelulusan Mahasiswa Universitas Dian Nuswantoro" oleh Yuda Septian Nugroho, menerapkan metode Nä̈ve Bayes untuk mengidentifikasi ketepatan waktu kelulusan mahasiswa Universitas Dian Nuswantoro Fakultas Ilmu Komputer angkatan 2009 berjenjang DIII dan S1. Atribut yang digunakan adalah NIM, Nama, Jenjang, Progdi, Provinsi Asal, Jenis Kelamin, SKS, IPK, dan Tahun Lulus. Hasil penelitian menunjukkan bahwa tingkat akurasi dengan model klasifikasi Naïve Bayes mencapai 82,08\%, yang artinya model akurasi tersebut terbukti baik, namun perlu ditinjau ulang baik dari segi kompleksitas dan jumlah datasetnya (Nugroho, 2013).

Penelitian lainnya dengan judul "Penerapan Metode Jaringan Syaraf Tiruan Backpropagation untuk Memprediksi Nilai Ujian Sekolah" oleh Sandy Kosasi. Penelitian tersebut menggunakan nilai mata pelajaran matematika dan IPA tahun ajaran 2010/2011, 2011/2012, dan 2012/2013. Hasil penelitian menunjukkan bahwa tingkat akurasi mencapai $80,15 \%$, yang artinya penerapan metode backpropagation dapat diandalkan untuk melakukan prediksi nilai ujian sekolah (Kosasi, 2014).

Berdasarkan penelitian terdahulu, penulis melakukan penelitian tentang "Implementasi Metode Backpropagation Neural Network (BNN) dalam Sistem Klasifikasi Ketepatan Waktu Kelulusan Mahasiswa (Studi Kasus: Program Studi Sistem Informasi Universitas Jember)". BNN digunakan karena penulis ingin mengetahui bagaimana penerapan metode BNN untuk mengklasifikasi ketepatan waktu kelulusan mahasiswa di Program Studi Sistem Informasi Universitas Jember. Selain itu, penulis juga ingin mengetahui bagaimana tingkat akurasi dalam penerapan metode ini.

\section{Tinjauan Pustaka}

Bagian ini membahas teori-teori dan pustaka yang digunakan dalam penelitian. Teori yang digunakan diambil dari literatur dan jurnal. Berikut teori yang akan digunakan dan dibahas dalam bagian ini.

\section{Data Mining}

Data Mining merupakan proses pengekstraksian informasi dari sekumpulan data yang sangat besar melalui penggunaan algoritma dan teknik penarikan dalam bidang statistik, pembelajaran mesin dan sistem manajemen basis data (Taruna R. \& Hiranwal, 2013). Dari definisi tersebut dapat ditarik kesimpulan bahwa datamining merupakan proses ataupun kegiatan untuk mengumpulkan dan mengolah data yang berukuran besar kemudian mengekstraksi data tersebut menjadi informasi - informasi yang nantinya dapat digunakan. Untuk proses pengolahan data dalam datamining, dapat dilihat pada Gambar 1.

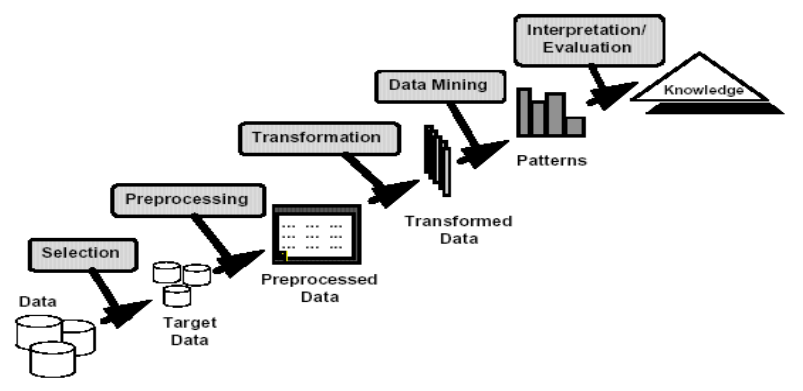

Gambar 1. Proses datamining (Ridwan, Suyono, \& Sarosa, 2013)

Gambar 1 menunjukkan proses pengolahan data dalam datamining yang dibagi menjadi beberapa tahap. Tahapan tersebut adalah sebagai berikut (Ridwan, Suyono, \& Sarosa, 2013):

1. Pembersihan data (Data Cleaning). Pembersihan data merupakan proses menghilangkan noise dan data yang tidak konsisten atau data tidak relevan.

2. Integrasi data (Data Integration). Integrasi data merupakan penggabungan data dari berbagai database ke dalam satu database baru.

3. Seleksi data (Data Selection). Data yang ada pada database sering kali tidak semuanya dipakai, oleh karena itu hanya data yang sesuai untuk dianalisis yang akan diambil dari database.

4. Transformasi data (Data Transformation). Data diubah atau digabung ke dalam format yang sesuai untuk diproses dalam Data Mining.

5. Proses Mining Merupakan suatu proses utama saat metode diterapkan untuk menemukan pengetahuan berharga dan tersembunyi dari data. Beberapa metode yang dapat digunakan berdasarkan pengelompokan Data Mining.

6. Evaluasi pola (Pattern Evaluation). Untuk mengidentifikasi pola-pola menarik ke dalam knowledge based yang ditemukan.

7. Presentasi pengetahuan (Knowledge Presentation). Merupakan visualisasi dan penyajian pengetahuan mengenai metode yang digunakan untuk memperoleh pengetahuan yang diperoleh pengguna.

\section{Klasifikasi}

Datamining merupakan ilmu yang digunakan untuk menganalisis data untuk mengkategorikan, mengelompokkan, dan menyimpulkannya. Proses tersebut terdapat teknik atau cara dalam mengelompokkan data pada data mining yang disebut sebagai klasifikasi. Klasifikasi merupakan proses menemukan model yang menggambarkan dan membedakan kelas data yang bertujuan untuk memperkirakan kelas dari objek yang belum diketahui labelnya (Han \& Kamber, 2006).

Blok Diagram Klasifikasi menunjukkan sebuah gambaran dari proses klasifikasi. Pada atribut set 
menunjukkan data input yang akan digunakan, kemudian diproses oleh klasifikasi dan akan menghasilkan output yang berupa kelas. Gambaran mengenai Blok Diagram Klasifikasi dapat dilihat pada gambar 2 (Joyonegoro, 2017).

$$
\text { Attribut Set }(x) \longmapsto \text { Classification Nodel } \longrightarrow \text { Class Label (y) }
$$

Gambar 2. Blok Diagram Klasifikasi

\section{Jaringan Syaraf Tiruan}

Jaringan syaraf tiruan adalah metode komputasi yang meniru jaringan syaraf biologis. Metode ini menggunakan perhitungan non-linear dasar yang disebut neuron dan saling berhubungan sehingga menyerupai jaringan syaraf manusia. Jaringan syaraf tiruan dibuat untuk memecahkan masalah pengenalan pola atau klasifikasi.

Jaringan saraf tiruan tidak diprogram untuk menghasilkan keluaran tertentu karena didasarkan pengalamannya selama mengikuti proses pembelajaran. Pada proses pembelajaran, ke dalam jaringan saraf tiruan dimasukkan pola-pola masukan (dan keluaran) lalu jaringan akan diajari untuk memberikan jawaban yang bisa diterima (Puspitaningrum, 2006).

Prinisp jaringan saraf tiruan (JST) ditentukan oleh tiga elemen dasar model saraf, yaitu:

1. Satu set dari sinapsis, atau penghubung yang masingmasing digolongkan oleh bobot atau kekuatannya.

2. Sebuah penambah untuk menjumlahkan sinyal-sinyal input. Ditimbang dari kekuatan sinaptik masing-masing neuron.

3. Sebuah fungsi aktivasi untuk membatasi amplitudo output dari neuron. Fungsi ini bertujuan membatasi jarak amplitude yang diperbolehkan oleh sinyal output menjadi sebuah angka yang terbatas.

Prinsip jaringan saraf tiruan secara sederhana digambarkan pada Gambar 3. dibawah ini:

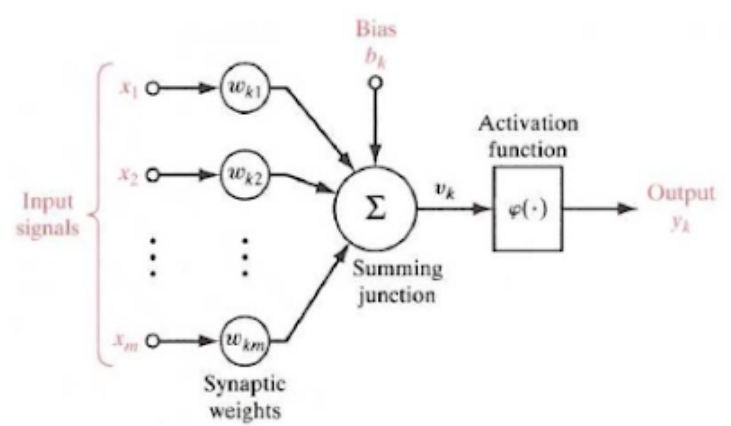

Gambar 3. Prinsip Jaringan Syaraf Tiruan

\section{Metode Backpropagation Neural Network (BNN)}

$B N N$ merupakan algoritma pelatihan jenis terawasi (supervised) yang mempunyai banyak lapisan. BNN menggunakan error output untuk mengubah nilai bobotbobotnya dalam arah mundur (backward). Untuk mendapatkan error ini, tahap perambatan maju (forward propagation) harus dikerjakan terlebih dahulu (Andrijasa \& Mistianingsih, 2010).

Metode pengenalan merupakan proses inisialisasi data yang akan diolah selanjutnya oleh $B N N$. Data yang akan dikenali disajikan dalam bentuk vektor. Masing-masing data mempunyai target yang disajikan juga dalam bentuk vektor. Target atau keluaran acuan merupakan suatu peta karakter yang menunjukkan lokasi dari vektor masukan. Sedangkan metode pelatihan merupakan proses latihan mengenali data dan menyimpan pengetahuan atau informasi yang didapat ke dalam bobot-bobot.

Terdapat 3 fase dalam pelatihan $B N N$, yaitu fase maju (feed forward), fase mundur (back propagation), dan fase modifikasi bobot. Dalam fase feed forward, pola masukan dihitung maju dimulai dari lapisan input hingga lapisan output. Dalam fase back propagation, tiap-tiap unit output menerima target pola yang berhubungan dengan pola input untuk dihitung nilai kesalahan. Kesalahan tersebut akan dipropagasikan mundur. Sedangkan fase modifikasi bobot bertujuan untuk menurunkan kesalahan yang terjadi. Ketiga fase tersebut diulang secara terus menerus hingga kondisi penghentian dipenuhi (Jumarwanto, 2009).

Langkah-langkah dari Metode Backpropagation Neural Network (BNN) menggunakan persamaan 2.1 sampai 2.9 (Siang, 2009):

Langkah 0: Inisialisasi semua bobot dengan bilangan acak kecil

Langkah 1: Jika kondisi penghentian belum terpenuhi, lakukan langkah $2-8$

Langkah 2: Untuk setiap pasang data pelatihan, lakukan langkah $3-8$

\section{Fase 1: Propagasi maju}

Langkah 3: Tiap unit masukkan menerima sinyal dan meneruskan ke unit tersembunyi

Langkah 4: Hitung semua keluaran di unit tersembunyi $\left(Z_{j}\right)$ :

$$
z_{i} v_{\mathrm{o} j}+\sum_{i=1}^{j} x_{i} v_{i j}
$$

$$
\begin{gathered}
j \\
z_{i} \\
z_{j}=f \dot{i}
\end{gathered}
$$

\section{Keterangan:}

$$
\begin{array}{ll}
\underset{z_{i}}{j} & =\text { nilai unit tersembunyi ke-j } \\
v_{0 j} & =\text { bobot layer } \text { input bias ke unit tersembunyi ke-j } \\
x_{i} & =\text { unit } \text { input } \mathrm{ke}-\mathrm{i} \\
v_{i j} & =\text { bobot unit } \text { input ke-i ke layer tersembunyi ke-j } \\
z_{j} & =\text { nilai unit tersembunyi ke-j menggunakan fungsi } \\
\text { aktivasi } & \text { sigmoid } \\
e & =\text { nilai konstanta }=2,718
\end{array}
$$

Langkah 5: Hitung semua jaringan di unit keluaran $\left(\mathrm{y}_{\mathrm{k}}\right)$ :

$$
\begin{aligned}
& y_{n} e t_{k}=w_{0 k}+\sum_{j=1}^{p} z_{j} w_{j k} \\
& y_{k}=f\left(y_{n} e t_{k}\right)=\frac{1}{1+e^{-y_{n} e t_{k}}}
\end{aligned}
$$

Keterangan:

$$
y_{n} \text { et }_{k}=\text { nilai unit output ke-k }
$$


$w_{0 k} \quad=$ bobot unit tersembunyi bias ke unit output ke-k

$w_{j k} \quad=$ bobot unit tersembunyi ke-j ke unit output ke-k

$y_{k} \quad=$ nilai unit output ke-k menggunakan fungsi

aktivasi sigmoid

\section{Fase 2: Propagasi mundur}

Langkah 6: Hitung faktor $\delta$ unit keluaran berdasarkan kesalahan di setiap unit keluaran:

$$
\delta_{k}=\left(t_{k}-y_{k}\right) f^{\prime}\left(y_{n} e t_{k}\right)=\left(t_{k}-y_{k}\right) \quad y_{k}(1
$$

$\delta_{\mathrm{k}}$ merupakan kesalahan yang akan dipakai dalam perubahan bobot layer dibawahnya (langkah 7), kemudian hitung suku perubahan bobot $\mathrm{w}_{\mathrm{jk}}$ (yang akan dipakai nanti untuk merubah bobot $\mathrm{w}_{\mathrm{jk}}$ ) dengan learning rate $\alpha$. Learning rate merupakan salah satu parameter yang digunakan untuk menghitung nilai perubahan bobot dengan range antara 0 sampai dengan 1 .

$$
\Delta w_{j k}=\alpha \delta_{k} z_{j}
$$

Keterangan:

$$
\begin{array}{ll}
\delta_{k} & =\text { nilai } \text { error } \text { unit output } \\
t_{k} & =\text { nilai target } \text { output } \\
a & =\text { learning rate } \\
\Delta w_{j k} & =\text { perubahan bobot unit tersembunyi ke-j ke unit }
\end{array}
$$
output ke-k

Langkah 7: Hitung faktor ${ }^{\star}$ unit tersembunyi berdasarkan kesalahan di setiap unit tersembunyi $\mathrm{z}_{\mathrm{j}}$

$$
\text { in e } t_{j}=\sum_{k=1}^{m} \dot{i} k w_{j k}
$$

Faktor kesalahan unit tersembunyi

$$
\delta_{j}=\delta_{n} \text { et } f_{j} f^{\prime}\left(z_{n} \text { et } t_{j}\right)=\delta_{n} \text { et } z_{j} z_{j}\left(1-z_{j}\right)
$$

Hitung suku perubahan bobot $\mathrm{v}_{\mathrm{ij}}$ (yang akan dipakai untuk merubah $v_{i j}$ )

$$
\Delta v_{i j}=\alpha \delta_{j} x_{i}
$$

Keterangan:

$\delta_{j} \quad=$ nilai error unit tersembunyi

$\Delta v_{i j}=$ perubahan bobot unit input ke-i ke unit tersembunyi ke-j

\section{Fase 3: Modifikasi bobot}

Langkah 8: Hitung semua perubahan bobot

Perubahan bobot garis yang menuju ke unit keluaran:

$$
w_{j k}(\text { bar } u)=w_{j k}(\operatorname{lam} a)+\Delta w_{j k}
$$

Perubahan bobot garis yang menuju ke unit tersembunyi:

$$
v_{i j}(\text { bar } u)=v_{i j}(\text { la } m a)+\Delta v_{i j}
$$

\section{Langkah 9: Selesai}

Setelah pelatihan selesai dilakukan maka dapat digunakan untuk pengenalan pola. Dalam hal ini, hanya Propagasi Maju (langah 4 dan 5) saja yang dipakai untuk menentukan keluaran. Apabila fungsi aktivasi yang dipakai bukan Sigmoid biner, maka langkah 4 dan 5 harus disesuaikan. Demikian juga turunannya pada langkah 6 dan 7.

Kondisi penghentian terpenuhi jika besarnya iterasi lebih besar dari besarnya iterasi maksimum yang telah ditetapkan. Iterasi merupakan rangkaian langkah dalam pembelajaran jaringan syaraf tiruan. Satu iterasi diartikan sebagai satu kali pembelajaran yang dilakukan pada langkah 2 sampai 8 .

\section{METODE PENELITIAN}

Bagian ini memaparkan tentang metode yang digunakan selama melakukan penelitian, seperti jenis penelitian, tempat dan waktu penelitian, tahapan penelitian, pengumpulan data, pengembangan sistem, serta gambaran sistem.

\section{Jenis Penelitian}

Jenis penelitian yang digunakan pada penelitian ini yaitu penelitian kuantitatif. Penelitian kuantitatif dipilih karena bertujuan menggambarkan benar tidaknya fakta-fakta yang ada serta menjelaskan tentang hubungan antar variabel yang diteliti sehingga bisa menjelaskan data yang diolah dengan cara mengumpulkan data, mengolah, menganalisis dan menginterpretasikan data dalam pengujian hipotesis statistik sehingga dapat teruji kebenarannya. Penggunaan metode kuantitatif dalam penulisan ini adalah pengumpulan data yang digunakan dalam bentuk angka..

\section{Tahapan Penelitian}

Tahapan pada penelitian ini terdiri dari 3 tahap, yaitu pengumpulan data, implementasi algoritma metode Backpropagation Neural Network (BNN), serta pengujian algoritma menggunakan uji performansi.

a. Tahap Pengumpulan Data

Pengumpulan data pada penelitian ini dibagi dalam 2 jenis, yaitu data primer dan data sekunder. Data primer diperoleh dengan melakukan wawancara kepada bagian Tata Usaha Program Studi Sistem Informasi Univerjsitas Jember dan UPTTI Universitas Jember, yang bertujuan untuk memperoleh data record studi mahasiswa PSSI UNEJ yang telah lulus. Data sekunder diperoleh dengan cara studi literatur melalui jurnal dan text book tentang datamining khususnya klasifikasi dan metode yang digunakan yaitu backpropagation neural network.

b. Pengujian Klasifikasi

Pengujian klasifikasi merupakan suatu pengujian yang dilakukan terhadap metode klasifikasi yang digunakan. Pengujian ini berguna untuk mengukur seberapa besar tingkat keakurasian data yang diperoleh dari hasil perhitungan metode tersebut. Pada penelitian ini, metode yang digunakan adalah Metode Backpropagation Neural Network (BNN).

Pengujian klasifikasi dalam sistem ini menggunakan uji performansi, yaitu menggunakan nilai akurasi, presisi, recall, dan F-Measure. Akurasi merupakan kedekatan antara nilai prediksi dan nilai sebenarnya. Presisi meupakan tingkat ketepatan antara informasi yang diminta pengguna dengan jawaban yang diberikan dari sistem. Recall merupakan tingkat keberhasilan sistem dalam menemukan kembali suatu informasi. F-measure merupakan perhitungan evaluasi dalam information retrieval yang menggabungkan precision dan recall.

Secara umum, penggunaan keempat istilah tersebut digambarkan dalam bentuk confusion matrix. Confusion matrix adalah salah satu alat ukur berbentuk matrik $2 \times 2$ yang digunakan untuk mengukur jumlah ketepatan algoritma yang dipakai. Confusion matrix disajikan pada tabel 1 (Widodo, Handayanto, \& Herlawati, 2013): 
Tabel 1. Confusion Matrix

\begin{tabular}{|c|c|c|c|}
\hline \multicolumn{2}{|c|}{} & \multicolumn{2}{|c|}{ Kelas Altual } \\
\cline { 3 - 4 } & True & True & False \\
\hline \multirow{4}{*}{ Kelas Prediksi } & $\begin{array}{c}\text { TP } \\
\text { (True Positive) }\end{array}$ & $\begin{array}{c}\text { FP } \\
\text { (False Positive) }\end{array}$ \\
\cline { 2 - 4 } & False & $\begin{array}{c}\text { FN } \\
\text { (False Negative) }\end{array}$ & $\begin{array}{c}\text { TN } \\
\text { (True Negative) }\end{array}$ \\
\hline
\end{tabular}

Keterangan:

- True Positive (TP) : Jika data yang diprediksi bernilai positif dan sesuai dengan nilai aktual (positif).

- False Positive (FP) : Jika data yang diprediksi tidak sesuai dengan nilai aktual.

- False Negative (FN) : Jika yang diprediksi bernilai negatif dan aktualnya positif.

- True Positive (TN) : Jika benar antara prediksi negatif dan aktualnya negatif.

Pengukuran nilai akurasi, presisi, recall, dan F-Measure berdasarkan confusion matrix dirumuskan pada persamaan 10 sampai 13:

$$
\begin{aligned}
& \text { Akurasi } \\
& = \\
& T P+F N+F P+T N \\
& T P+T N \frac{i}{i} \\
& \begin{array}{c}
T P+F N \\
T P \frac{\dot{b}}{\dot{b}}
\end{array} \\
& \text { Recall } \\
& =T P+F P \\
& T P \frac{\dot{i}}{i} \\
& F \text {-Measure } \quad=2 \times T P+F P+F N \\
& 2 \times T P \frac{i}{i}
\end{aligned}
$$

c. Perancangan Sistem Klasifikasi Ketepatan Waktu Kelulusan Mahasiswa PSSI UNEJ

Dalam mengimplementasikan algoritma, terdapat beberapa tahap yang disesuaikan dengan metode Software Development Life Cycle (SDLC) waterfall. Model waterfall dibagi menjadi beberapa tahap yaitu: analisisis kebutuhan, desain sistem, implementasi, pengujian dan pemeliharaan. Metode ini memiliki pendekatan secara sistematik dan sekuensial untuk pengembangan perangkat lunak yang terstruktur tahapan demi tahapan. Model Waterfall terdiri dari analisis kebutuhan, desain sistem, implementasi, dan pengujian.

\section{Analisis Kebutuhan}

Tahapan dalam menganalisis kebutuhan yaitu berdasarkan pada informasi primer yang diperoleh dari hasil wawancara serta informasi sekunder yang diperoleh dari buku-buku, studi pustaka dan karya ilmiah. Selain itu, analisis kebutuhan dilakukan untuk menentukan kebutuhan fungsional dan non fungsional dari sistem klasifikasi ketepatan waktu kelulusan mahasiswa Program Studi Sistem Informasi Universitas Jember ini.

\section{Desain Sistem}

Tahap selanjutnya yaitu desain sistem, dimana pada penlitian ini menggunakan Unified Modeling Language (UML) yang dirancang dengan konsep Object-Oriented Programming (OOP). Pemodelan UML yang digunakan berupa elemen input proses output, usecase diagram, scenario diagram, activity diagram, sequence diagram, class diagram, dan entity relationship diagram.

3. Implementasi

Tahap implementasi merupakan tahapan untuk mengimplementasikan desain yang telah dirancang ke dalam program. Hal yang dilakukan dalam implementasi antara lain:

a. Penulisan kode program (programming) menggunakan bahasa menggunakan bahasa Java dan menggunakan Netbeans sebagai IDE-nya.

b. Menajemen basisdata menggunakan MySQL.

\section{Pengujian Sistem}

Pada tahap ini dilakukan pengujian terhadap aplikasi yang telah dibuat, pengujian aplikasi dilakukan menggunakan metode Black box testing. Pengujian ini yang melibatkan pengguna/user, dimana hanya memperhatikan fungsionalitas yang berkaitan dengan masukan/keluaran (I/O) apakah sesuai dengan sistem yang dijalankan.

a. Gambaran Sistem

Sistem yang dibuat merupakan sistem untuk mengklasifikasi ketepatan waktu kelulusan mahasiswa Program Studi Sistem Informasi Universitas Jember menggunakan metode jaringan syaraf tiruan backpropagation. Sistem ini dapat melakukan klasifikasi berdasarkan dataset lulusan mahasiswa Program Studi Sistem Informasi Universitas Jember angkatan tahun 20112013. Atribut yang digunakan untuk klasifikasi berjumlah 9 atribut, yaitu nilai IP semester 1 sampai 6, jumlah SKS yang ditempuh, semester saat terakhir kali memprogram matakuliah KKN dan PKL. Kelas yang digunakan untuk klasifikasi yaitu ketepatan waktu lulus mahasiswa tersebut. Penentuan ketepatan waktunya yaitu jika masa studi kurang dari sama dengan 60 bulan, maka mahasiswa tersebut lulus tepat waktu dan jika lebih dari 60 bulan maka tidak tepat waktu.

Penelitian ini menggunakan metode jaringan syaraf tiruan backpropagation dengan arsitektur jaringan 9-3-1, yang artinya arsitektur tersebut mengandung 9 neuron pada layer input, 3 neuron pada layer tersembunyi, dan 1 neuron pada layer output. Neuron pada layer input yaitu atribut yang terdapat pada data mahasiswa, sementara neuron pada layer output yaitu kelas yang terdapat pada data mahasiswa. Peneliti menggunakan 3 buah neuron pada layer tersembunyi karena berdasarkan penelitian yang berjudul "Jaringan Syaraf Tiruan Algoritma Backpropagation dalam Memprediksi Ketersediaan Komoditi Pangan Provinsi Riau", oleh Eka Pandu Cynthia dan Edi Ismanto, yang menyatakan bahwa penelitian dengan menggunakan 3 buah neuron pada layer tersembunyi, menghasilkan tingkat akurasi sebesar 99,97\% dalam memprediksi ketersediaan komoditi pangan Provinsi Riau (Cynthia \& Ismanto, 2017).

Tahap awal dalam sistem ini yaitu sekumpulan dataset lulusan mahasiswa tersebut dinormalisasi menggunakan fungsi aktivasi sigmoid (biner), baik seluruh atribut maupun kelasnya, dengan interval $[0.1,0.9]$. Rumus untuk normalisasinya yaitu (Siang, 2009):

$$
x^{\prime}=\frac{0.8(x-a)}{b-a}+0.1
$$

keterangan:

$$
x^{\prime}=\text { nilai data ke-n setelah dinormalisasi }
$$


$x=$ nilai data ke-n

$a=$ data nilai minimum

$b=$ data nilai maksimum

Setelah data dinormalisasi, proses pelatihan backpropagation dimulai dari propagasi maju untuk mengecek errornya dan akan mengalami propagasi mundur untuk memperbaiki bobot. Proses backpropagation dinyatakan selesai jika kondisi penghentian terpenuhi. Pada penelitian ini, penghentian dipenuhi jika nilai iterasinya telah mencapai batas maksimum iterasi yang ditentukan.

Dataset yang digunakan pada sistem ini menggunakan dataset full train full test. Setelah proses pelatihan backpropagation dinyatakan selesai, maka proses testing dilakukan dengan menggunakan dataset dari proses pelatihan (training) untuk mengukur uji performansi menggunakan persamaan 10 sampai 13 .

2. Pengembangan Sistem

Bagian ini terdiri dari analisis kebutuhan sistem dan desain sistem.

\section{Analisis Kebutuhan}

Analisis kebutuhan perangkat lunak dalam penelitian ini yaitu dengan cara mengidentifikasi permasalahan yang ada untuk dijadikan bahan dalam membuat sistem klasifikasi ketepatan waktu kelulusan mahasiswa Program Studi Sistem Informasi Univeristas Jember. Analisis kebutuhan yang dilakukan meliputi kebutuhan fungsional dan nonfungsional, yang diperoleh dari anallisis hasil wawancara dan studi literatur.

Kebutuhan fungsional dalam sistem ini antara lain:

1. Sistem dapat mengelola insert user baru melalui fitur sign in.

2. Sistem dapat mengubah data user yang sedang aktif.

3. Sistem dapat menampilkan data yudisi (bagi aktor admin dan user).

4. Sistem dapat mengelola insert, update, dan delete data yudisi (bagi aktor user).

5. Sistem dapat menampilkan data mahasiswa (bagi aktor admin dan user)

6. Sistem dapat mengelola insert, update, dan delete data mahasiswa (bagi aktor user).

7. Sistem dapat melakukan penghitungan klasifikasi dan akurasi data mahasiswa menggunakan metode backpropagation.

8. Sistem dapat menampilkan hasil klasifikasi dan akurasi data mahasiswa menggunakan metode backpropagation.

Kebutuhan non-fungsional dari sistem ini antara lain:

1. Sistem yang dibangun berbentuk desktop.

2. Sistem menggunakan bahasa pemrograman Java dengan konsep OOP (Object Oriented Programming).

3. Sistem menggunakan tampilan secara user friendly, sehingga pengguna tidak kesulitan saat mengoperasikannya.

\section{Desain Sistem}

Desain sistem merupakan tahap pembuatan diagram sistem yang menggunakan Unified Modeling Language (UML) dengan konsep Object-Oriented Programing (OOP) Desain sistem meliputi Business Process, Usecase Diagram, dan Entity Relationship Diagram (ERD).

1. Elemen Input Proses Output

Elemen input proses output digunakan untuk menggambarkan input data yang dibutuhkan sistem, output dari sistem, serta tujuan pembuatan sistem. Elemen input proses output sistem dapat dilihat pada Gambar 4.

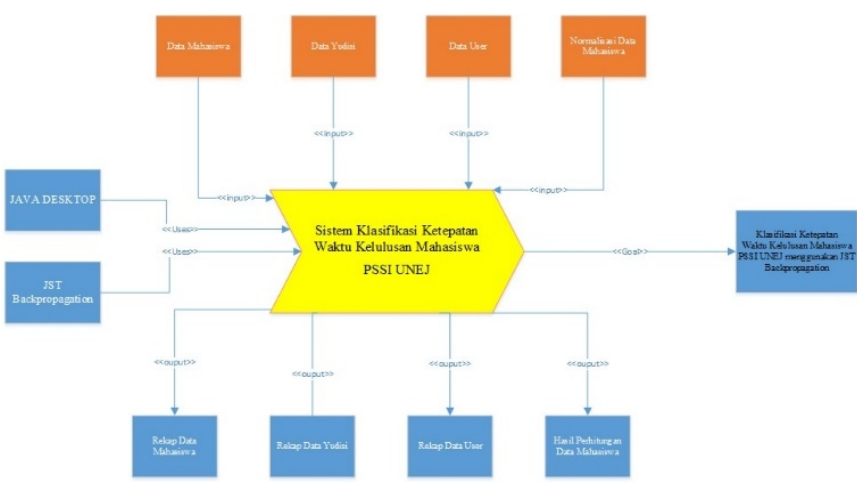

Gambar 4. Elemen Input Proses Output

\section{Usecase Diagram}

Usecase Diagram digunakan untuk menggambarkan fitur apa saja yang dibuat pada sistem klasifikasi ketepatan waktu kelulusan mahasiswa Program Studi Sistem Informasi Univeristas Jember (PSSI UNEJ) menggunakan implementasi algoritma jaringan syaraf tiruan backpropagation. Usecase Diagram dapat dilihat pada Gambar 5 .

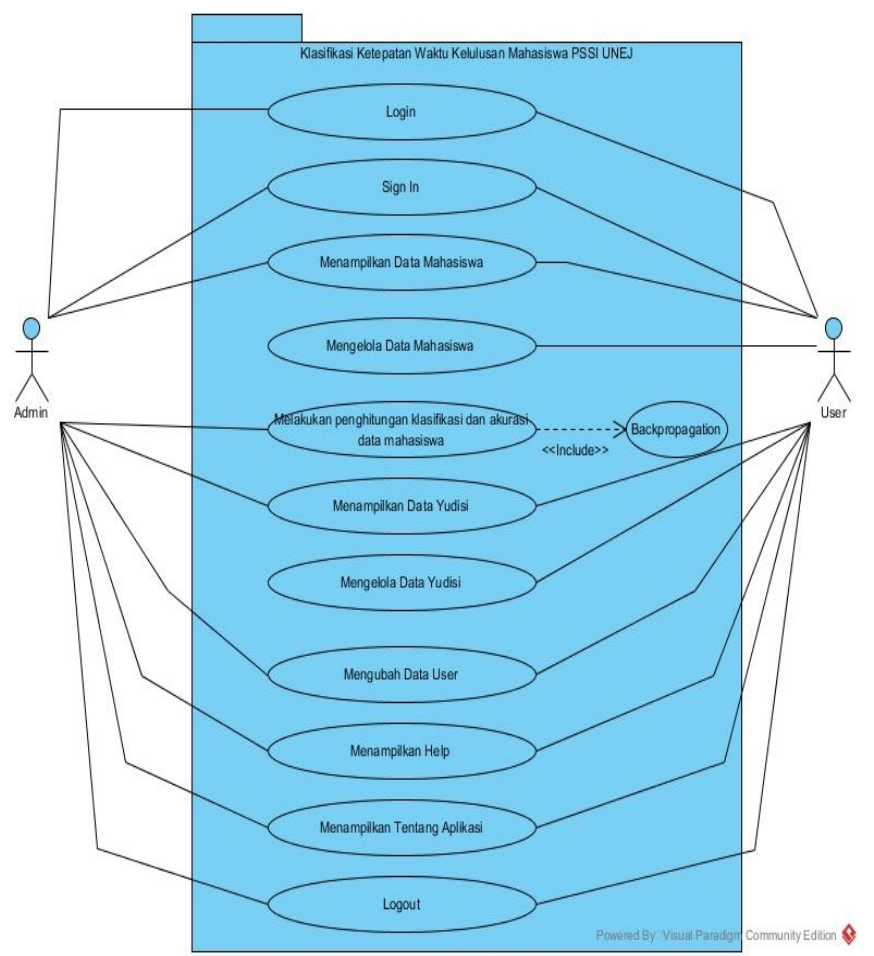

Gambar 5. Usecase Diagram

\section{Entity Relationship Diagram (ERD)}

Entity Relationship Diagram merupakan merupakan suatu model untuk menjelaskan hubungan antar data dalam basis data berdasarkan objek-objek dasar data yang mempunyai hubungan antar relasi. Entity Relationship Diagram untuk sistem klasifikasi ketepatan waktu kelulusan mahasiswa PSSI UNEJ dapat dilihat pada Gambar 6. 


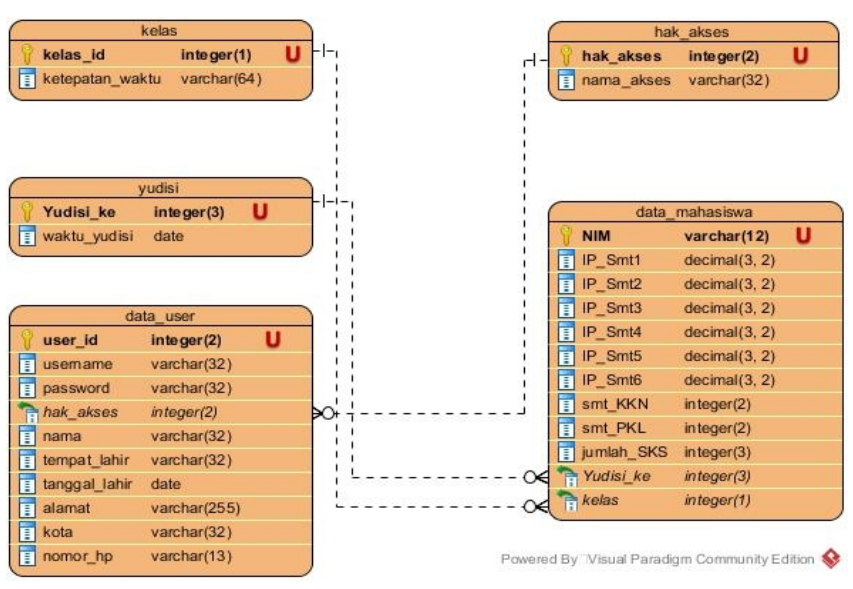

Gambar 6. Entity Relationship Diagram.

\section{HASIL DAN PEMBAHASAN}

Bab ini menjelaskan mengenai hasil penelitian yang telah dilakukan serta pembahasan sistem yang telah dibuat. Pembahasan dilakukan guna menjelaskan dan memaparkan bagaimana penelitian ini seperti apa yang telah ditemukan pada awal penelitian.

\section{Hasil Implementasi Metode Jaringan Syaraf Tiruan Backpropagation}

Pada penelitian ini, implementasi metode jaringan syaraf tiruan Bacpropagation digunakan pada proses perhitungan klasifikasi ketepatan waktu kelulusan mahasiswa Program Studi Sistem Informasi Universitas Jember (PSSI UNEJ). Perhitungan dilakukan dari data lulusan mahasiswa PSSI UNEJ yang diperoleh dari bagian akademik Program Studi Sistem Informasi Universitas Jember dan manajer UPTTI Universitas Jember.

Sebelum melakukan perhitungan, maka dilakukan pembersihan data (Data Cleaning) terlebih dahulu untuk menghilangkan noise dan data yang tidak konsisten atau data tidak relevan. Dari bagian akademik Program Studi Sistem Informasi Universitas Jember, diperoleh 314 record data lulusan PSSI UNEJ angkatan 2009-2013, sementara dari manajer UPTTI Univeristas Jember diperoleh sebanyak 346 record. Setelah dilakukan pembersihan data, hasilnya diperoleh sebanyak 169 record lulusan mahasiswa PSSI UNEJ angkatan 2011-2013, karena untuk angkatan 20092010 ada data kosong yang tidak dapat digunakan untuk proses perhitungan klasifikasi, yaitu pada IP Semester 1-4 (untuk angkatan 2009) dan IP Semester 1-2 (untuk angkatan 2010). Atribut tersebut berisi nilai 0,00 karena tidak terdeteksi oleh Sistem Informasi Terpadu (SISTER). Data lulusan mahasiswa yang telah dilakukan pembersihan data dapat dilihat pada Tabel 2.

Tabel 2. Data Lulusan Mahasiswa PSSI UNEJ

\begin{tabular}{|c|c|c|c|c|c|c|c|c|c|c|c|}
\hline \multirow{2}{*}{ No } & \multirow{2}{*}{ NIM } & \multicolumn{6}{|c|}{ Indeks Prestasi (Semester) } & \multirow{2}{*}{$\begin{array}{c}\text { Semester saat } \\
\text { Pemrograman KKN }\end{array}$} & \multirow{2}{*}{$\begin{array}{c}\text { Semester saat } \\
\text { Pemrograman PKL }\end{array}$} & \multirow{2}{*}{ SKS } & \multirow{2}{*}{$\begin{array}{c}\text { Lama Stud } \\
\text { (bulan) }\end{array}$} \\
\hline & & 1 & 2 & 3 & 4 & 5 & 6 & & & & \\
\hline 1 & 112410101001 & 3.20 & 3.22 & 3.63 & 3.54 & 3.57 & 3.70 & 7 & 7 & 148 & 46.93 \\
\hline 2 & 112410101002 & 3.75 & 3.65 & 3.79 & 3.92 & 3.87 & 4.00 & 7 & 6 & 148 & 46.5 \\
\hline 3 & 112410101003 & 2.25 & 2.83 & 2.95 & 2.81 & 3.10 & 3.35 & 8 & 7 & 146 & 52.1 \\
\hline 4 & 112410101005 & 2.60 & 2.90 & 2.29 & 2.44 & 3.11 & 3.21 & 8 & 7 & 147 & 46.73 \\
\hline 5 & 112410101007 & 3.30 & 3.74 & 3.71 & 3.54 & 3.81 & 3.50 & 7 & 6 & 148 & 69.23 \\
\hline 6 & 112410101008 & 3.55 & 3.17 & 3.67 & 3.29 & 3.14 & 3.73 & 7 & 7 & 148 & 49.57 \\
\hline 7 & 112410101011 & 3.10 & 3.00 & 3.21 & 2.50 & 3.48 & 3.50 & 7 & 6 & 148 & 51.13 \\
\hline 8 & 112410101012 & 2.45 & 2.22 & 2.50 & 3.00 & 2.63 & 3.24 & 8 & 7 & 147 & 63.80 \\
\hline 9 & 112410101013 & 2.30 & 3.00 & 3.04 & 3.13 & 3.26 & 3.17 & 8 & 7 & 147 & 52.1 \\
\hline 10 & 112410101015 & 3.10 & 3.17 & 2.88 & 3.05 & 3.35 & 3.70 & 8 & 6 & 148 & 52.1 \\
\hline$\ldots$ & $\ldots$ & $\ldots$ & $\ldots$ & $\ldots$ & $\ldots$ & $\ldots$ & $\ldots$ & $\ldots$ & $\ldots$ & $\ldots$ & $\ldots$ \\
\hline 169 & 132410101092 & 3.60 & 3.30 & 3.48 & 3.36 & 3.39 & 3.60 & 7 & 7 & 145 & 44.57 \\
\hline
\end{tabular}

Tabel 4. Nilai Minimum dan Maksimum Masing-masing Atribut dan Kelas

\begin{tabular}{|c|l|c|c|}
\hline NO & \multicolumn{1}{|c|}{ Atribut / Kelas } & $\begin{array}{c}\text { Nilai } \\
\text { Minimum }\end{array}$ & $\begin{array}{c}\text { Nilai } \\
\text { Maksimum }\end{array}$ \\
\hline 1 & IP semester 1 & 0 & 4 \\
\hline 2 & IP semester 2 & 0 & 4 \\
\hline 3 & IP semester 3 & 0 & 4 \\
\hline 4 & IP semester 4 & 0 & 4 \\
\hline 5 & IP semester 5 & 0 & 4 \\
\hline 6 & IP semester 6 & 0 & 4 \\
\hline 7 & $\begin{array}{l}\text { Semester saat terakhir kali memprogram } \\
\text { matakuliah KKN }\end{array}$ & 7 & 9 \\
\hline 8 & $\begin{array}{l}\text { Semester saat terakhir kali memprogram } \\
\text { matakuliah PKL }\end{array}$ & 6 & 9 \\
\hline 9 & Jumlah SKS yang ditempuh & 144 & 153 \\
\hline 10 & Kelas & 1 & 2 \\
\hline
\end{tabular}


Tabel 5. Hasil Normalisasi Data Mahasiswa

\begin{tabular}{|c|c|c|c|c|c|c|c|c|c|c|c|}
\hline No & NIM & IP Semester 1 & IP Semester 2 & IP Semester 3 & IP Semester 4 & IP Semester 5 & IP Semester 6 & $\begin{array}{c}\text { Semester } \\
\text { KKN }\end{array}$ & $\begin{array}{c}\text { Semester } \\
\text { PKL }\end{array}$ & $\begin{array}{c}\text { Jumlah } \\
\text { SKS }\end{array}$ & \begin{tabular}{c} 
Kelas \\
\hline 1
\end{tabular} \\
\hline 112410101001 & 0.740 & 0.744 & 0.826 & 0.808 & 0.814 & 0.840 & 0.100 & 0.367 & 0.456 & 0.1 \\
\hline 2 & 112410101002 & 0.850 & 0.830 & 0.858 & 0.884 & 0.874 & 0.900 & 0.100 & 0.100 & 0.456 & 0.1 \\
\hline 3 & 112410101003 & 0.550 & 0.666 & 0.690 & 0.662 & 0.720 & 0.770 & 0.500 & 0.367 & 0.278 & 0.1 \\
\hline 4 & 112410101005 & 0.620 & 0.680 & 0.558 & 0.588 & 0.722 & 0.742 & 0.500 & 0.367 & 0.367 & 0.1 \\
\hline 5 & 112410101007 & 0.760 & 0.848 & 0.842 & 0.808 & 0.862 & 0.800 & 0.100 & 0.100 & 0.456 & 0.9 \\
\hline 6 & 112410101008 & 0.810 & 0.734 & 0.834 & 0.758 & 0.728 & 0.846 & 0.100 & 0.367 & 0.456 & 0.1 \\
\hline 7 & 112410101011 & 0.720 & 0.700 & 0.742 & 0.600 & 0.796 & 0.800 & 0.100 & 0.100 & 0.456 & 0.1 \\
\hline 8 & 112410101012 & 0.590 & 0.544 & 0.600 & 0.700 & 0.626 & 0.748 & 0.500 & 0.367 & 0.367 & 0.9 \\
\hline 9 & 112410101013 & 0.560 & 0.700 & 0.708 & 0.726 & 0.752 & 0.734 & 0.500 & 0.367 & 0.367 & 0.1 \\
\hline 10 & 112410101015 & 0.720 & 0.734 & 0.676 & 0.710 & 0.770 & 0.840 & 0.500 & 0.100 & 0.456 & 0.1 \\
\hline$\ldots$ & $\ldots$ & $\ldots$ & $\ldots$ & $\ldots$ & $\ldots$ & $\ldots$ & $\ldots$ & $\ldots$ & $\ldots$ & $\ldots$ & $\ldots$ \\
\hline 169 & 132410101092 & 0.820 & 0.760 & 0.796 & 0.772 & 0.778 & 0.820 & 0.100 & 0.367 & 0.189 & 0.1 \\
\hline
\end{tabular}

Klasifikasi ketepatan waktu keluluasn mahasiswa didapatkan berdasarkan lama studi dari masing-masing mahasiswa. Untuk program sarjana, mahasiswa memiliki beban pembelajaran sekurang-kurangnya 144 SKS dengan masa studi selama 4-5 tahun (UNEJ, 2015). Oleh karena itu, mahasiswa diklasifikasikan lulus tepat waktu jika lama studinya kurang dari atau sama dengan 5 tahun (60 bulan). Jika lebih dari 5 tahun (60 bulan) maka tidak tepat waktu. Klasifikasi berdasarkan lama studi ditunjukkan pada tabel 3.

Tabel 3. Klasifikasi Berdasarkan Lama Studi

\begin{tabular}{|c|c|c|c|}
\hline NO & Lama Studi & Klasifikasi & Nilai Klasifikasi \\
\hline 1 & Kurang dari atau sama dengan 60 bulan & Tepat Waktu & 1 \\
\hline 2 & Lebih dari 60 bulan & Tidak Tepat Waktu & 2 \\
\hline
\end{tabular}

Setelah melakukan pembersihan data, data dinormalisasi menggunakan fungsi aktivasi sigmoid (biner), baik seluruh atribut maupun kelasnya, dengan interval [0.1, 0.9]. Berdasarkan persamaan 14, nilai minimum dan maksimum dari masing-masing atribut dan kelas ditunjukkan pada tabel 4, sementara hasil normalisasi ditunjukkan pada Tabel 5.

Setelah seluruh data dinormalisasi, maka tahapan selanjutnya yaitu melakukan langkah-langkah penghitungan metode Backpropagation menggunakan persamaan 1 sampai dengan 9. Pada penelitian ini, arsitektur yang digunakan dalam jaringan syaraf tiruan Backpropagation yaitu 9-3-1. Artinya, arsitektur tersebut mengandung 9 neuron pada layer input, 3 neuron pada layer tersembunyi, dan 1 neuron pada layer output. Neuron pada layer input yaitu atribut yang terdapat pada data mahasiswa, sementara neuron pada layer output yaitu kelas yang terdapat pada data mahasiswa.

\section{Uji Performansi}

Uji performansi dilakukan untuk mengukur seberapa baik penggunaan metode jaringan syaraf tiruan Backpropagation untuk mengklasifikasi ketepatan waktu kelulusan mahasiswa PSSI UNEJ jika dilihat dari nilai akurasi, presisi, recall, dan F-Measure. Pengujian dilakukan dengan menganalisis nilai kelas prediksi untuk learning rate $0,1,0,3,0,5,0,7$, dan 0,9 dengan batas iterasi masing-masing 1.000, 2.000, dan 3.000 iterasi. Hasil akurasi, presisi, recall dan F-Measure dapat dilihat pada tabel 6 sampai 9.

Tabel 6. Nilai Akurasi

\begin{tabular}{|c|c|c|c|c|c|c|}
\hline \multicolumn{2}{|c|}{} & \multicolumn{5}{|c|}{ Learning Rate } \\
\cline { 3 - 7 } \multicolumn{2}{|c|}{} & 0.1 & 0.3 & 0.5 & 0.7 & 0.9 \\
\hline \multirow{3}{*}{$\begin{array}{c}\text { Batas } \\
\text { Iterasi }\end{array}$} & 1000 & $95.27 \%$ & $95.86 \%$ & $95.86 \%$ & $95.86 \%$ & $95.86 \%$ \\
\cline { 2 - 7 } & 2000 & $97.63 \%$ & $97.04 \%$ & $97.04 \%$ & $98.82 \%$ & $98.82 \%$ \\
\cline { 2 - 7 } & 3000 & $97.63 \%$ & $97.04 \%$ & $98.82 \%$ & $98.82 \%$ & $98.82 \%$ \\
\hline
\end{tabular}

Tabel 7. Nilai Presisi

\begin{tabular}{|c|c|c|c|c|c|c|}
\hline \multicolumn{2}{|c|}{} & \multicolumn{5}{|c|}{ Learning Rate } \\
\cline { 3 - 7 } \multicolumn{2}{|c|}{} & 0.1 & 0.3 & 0.5 & 0.7 & 0.9 \\
\hline \multirow{3}{*}{$\begin{array}{c}\text { Batas } \\
\text { Iterasi }\end{array}$} & 1000 & $95.63 \%$ & $95.65 \%$ & $95.65 \%$ & $95.65 \%$ & $95.65 \%$ \\
\cline { 2 - 7 } & 2000 & $97.47 \%$ & $96.86 \%$ & $96.86 \%$ & $98.72 \%$ & $98.72 \%$ \\
\cline { 2 - 7 } & 3000 & $97.47 \%$ & $96.86 \%$ & $98.72 \%$ & $98.72 \%$ & $98.72 \%$ \\
\hline
\end{tabular}

Tabel 8. Nilai Recall

\begin{tabular}{|c|c|c|c|c|c|c|}
\hline \multicolumn{2}{|c|}{} & \multicolumn{5}{|c|}{ Learning Rate } \\
\cline { 3 - 7 } \multicolumn{2}{|c|}{} & 0.1 & 0.3 & 0.5 & 0.7 & 0.9 \\
\hline \multirow{3}{*}{$\begin{array}{c}\text { Batas } \\
\text { Iterasi }\end{array}$} & 1000 & $99.35 \%$ & $100.00 \%$ & $100.00 \%$ & $100.00 \%$ & $100.00 \%$ \\
\cline { 2 - 7 } & 2000 & $100.00 \%$ & $100.00 \%$ & $100.00 \%$ & $100.00 \%$ & $100.00 \%$ \\
\cline { 2 - 7 } & 3000 & $100.00 \%$ & $100.00 \%$ & $100.00 \%$ & $100.00 \%$ & $100.00 \%$ \\
\hline
\end{tabular}

Tabel 9. Nilai F-Measure

\begin{tabular}{|c|c|c|c|c|c|c|}
\hline \multicolumn{2}{|c|}{} & \multicolumn{5}{|c|}{ Learning Rate } \\
\cline { 3 - 7 } \multicolumn{2}{|c|}{} & 0.1 & 0.3 & 0.5 & 0.7 & 0.9 \\
\hline \multirow{3}{*}{$\begin{array}{c}\text { Batas } \\
\text { Iterasi }\end{array}$} & 1000 & $97.45 \%$ & $97.78 \%$ & $97.78 \%$ & $97.78 \%$ & $97.78 \%$ \\
\cline { 2 - 7 } & 2000 & $98.72 \%$ & $98.40 \%$ & $98.40 \%$ & $99.35 \%$ & $99.35 \%$ \\
\cline { 2 - 7 } & 3000 & $98.72 \%$ & $98.40 \%$ & $99.35 \%$ & $99.35 \%$ & $99.35 \%$ \\
\hline
\end{tabular}

Berdasarkan tabel 6 sampai 9, dapat disimpulkan bahwa penggunaan metode jaringan syaraf tiruan Backpropagation untuk klasifikasi ketepatan waktu kelulusan mahasiswa PSSI UNEJ memiliki nilai akurasi, presisi, recall, dan $F$ Measure yang tinggi. Nilai akurasi tertinggi yaitu sebesar $98,82 \%$ pada iterasi ke-2000 dan 3000, masing-masing dengan learning rate $=0,7$ dan 0,9 untuk iterasi ke-2000 dan learning rate $=0,5,0,7$ dan 0,9 untuk iterasi ke-3000. Nilai akurasi tersebut didapat dari jumlah data benar sebanyak 167 data dari 169 data secara keseluruhan. Nilai presisi tertinggi yaitu sebesar $98,72 \%$ pada iterasi ke-2000 dan 3000, masing-masing dengan learning rate $=0,7$ dan 0,9 untuk iterasi ke-2000 dan learning rate $=0,5,0,7$ dan 0,9 untuk iterasi ke-3000. Nilai recall tertinggi yaitu 
sebesar $100,00 \%$ pada semua learning rate dan batas iterasi, kecuali pada learning rate $=0,1$ untuk iterasi ke1000 yaitu sebesar 99,35\%. Nilai F-Measure tertinggi yaitu sebesar 99,35\% pada iterasi ke-2000 dan 3000, masingmasing dengan learning rate $=0,7$ dan 0,9 untuk iterasi ke2000 dan learning rate $=0,5,0,7$ dan 0,9 untuk iterasi ke3000 .

\section{KESIMPULAN}

Kesimpulan dari penelitian ini adalah metode jaringan syaraf tiruan Backpropagation untuk klasifikasi ketepatan waktu kelulusan mahasiswa PSSI UNEJ memiliki nilai akurasi, presisi, recall, dan F-Measure yang tinggi. Nilai akurasi tertinggi yaitu sebesar $98,82 \%$ pada iterasi ke-2000 dan 3000, masing-masing dengan learning rate $=0,7$ dan 0,9 untuk iterasi ke-2000 dan learning rate $=0,5,0,7$ dan 0,9 untuk iterasi ke-3000. Nilai akurasi tersebut didapat dari jumlah data benar sebanyak 167 data dari 169 data secara keseluruhan. Nilai presisi tertinggi yaitu sebesar 98,72\% pada iterasi ke-2000 dan 3000, masing-masing dengan learning rate $=0,7$ dan 0,9 untuk iterasi ke-2000 dan learning rate $=0,5,0,7$ dan 0,9 untuk iterasi ke-3000. Nilai recall tertinggi yaitu sebesar $100,00 \%$ pada semua learning rate dan batas iterasi, kecuali pada learning rate $=0,1$ untuk iterasi ke-1000 yaitu sebesar 99,35\%. Nilai $F$ Measure tertinggi yaitu sebesar $99,35 \%$ pada iterasi ke2000 dan 3000, masing-masing dengan learning rate $=0,7$ dan 0,9 untuk iterasi ke-2000 dan learning rate $=0,5,0,7$ dan 0,9 untuk iterasi ke-3000.

Penerapan metode jaringan syaraf tiruan Backpropagation dalam sistem klasifikasi ketepatan waktu kelulusan mahasiswa PSSI UNEJ dilakukan dengan beberapa tahapan. Tahapan pertama yaitu mengumpulkan data lulusan mahasiswa PSSI UNEJ yang diperoleh dari Tata Usaha PSSI UNEJ dan UPTTI UNEJ. Tahapan kedua yaitu melakukan pembersihan data (Data Cleaning) untuk menghilangkan noise dan data yang tidak konsisten atau data tidak relevan, sehingga diperoleh 169 record data lulusan mahasiswa.PSSI UNEJ angkatan 2011-2013. Tahapan ketiga yaitu melakukan perhitungan metode Backpropagation. Pada penelitian ini, arsitektur yang digunakan dalam jaringan syaraf tiruan Backpropagation yaitu 9-3-1, yang artinya arsitektur tersebut mengandung 9 neuron pada layer input, 3 neuron pada layer tersembunyi, dan 1 neuron pada layer output. Neuron pada layer input meliputi atribut yang terdapat pada data mahasiswa, yaitu IP semester 1-6, jumlah SKS, dan semester saat terakhir kali memprogram matakuliah KKN dan PKL. Neuron pada layer output meliputi kelas yang terdapat pada data mahasiswa, dengan asumsi bahwa jika masa studi kurang dari atau sama dengan 60 bulan, maka diklasifikasikan lulus tepat waktu, demikian sebaliknya.

\section{SARAN}

Saran yang dapat diberikan sebagai masukan yang lebih baik yaitu berpua penambahan atribut cuti dan atribut skripsi bisa dilakukan pada penelitian selanjutnya untuk mengetahui pengaruh tingkat akurasi pada klasifikaasi. Selain itu penambahan neuron pada layer tersembunyi sejumlah layer input juga bisa dilakukan pada penelitian selanjutnya untuk mengetahui pengaruh tingkat akurasi pada klasifikaasi.

\section{DAFTAR PUSTAKA}

[1] Andrijasa, M., \& Mistianingsih. (2010). Penerapan Jaringan Syaraf Tiruan untuk Memprediksi Jumlah Pengangguran di Provinsi Kalimantan Timur dengan Menggunakan Algoritma Pembelajaran Backpropagation. Jurnal Informatika Mulawarman.

[2] Cynthia, E. P., \& Ismanto, E. (2017). Jaringan Syaraf Tiruan Backpropagation dalam Memprediksi Ketersediaan Komoditi Pangan Provinsi Riau. Seminar Nasional Teknologi Informasi, Komunikasi dan Industri (SNTIKI) 9, 271-282.

[3] Han, J., \& Kamber, M. (2006). Data Mining: Concepts and Techniques. SunFransisco: Morgan Kaufmann Publishers.

[4] Joyonegoro, F. (2017). Implementasi K-Nearest Neighbor (KNN) pada Klasifikasi Tanaman Holtikultura Sesuai dengan Media Tanam dan Lingkungan.

[5] Jumarwanto, A. (2009). Aplikasi Jaringan Syaraf Tiruan Backpropagation untuk Memprediksi Penyakit THT di Rumah Sakit Mardi Rahayu Kudus. Jurnal Teknik Elektro.

[6] Puspitaningrum, D. (2006). Pengantar Jaringan Syaraf Tiruan. Yogyakarta: Andi.

[7] Ridwan, M., Suyono, H., \& Sarosa, M. (2013). Penerapan Data Mining untuk Evaluasi Kinerja Akademik Mahasiswa Menggunakan Algoritma Naive Bayes Classifier. Jurnal EECCIS, 1(7), 59-64.

[8] Siang, J. J. (2009). Jaringan Syaraf Tiruan dan Pemrogramannya Menggunakan Mathlab. Yogyakarta: Pen.

[9] Taruna R., S., \& Hiranwal, S. (2013). Enhanced Naive Bayes Algorithm for Intrusion Detection. International Journal of Computer Science and Information Technologies, 6(4), 960-962.

[10] UNEJ, T. (2015). Pedoman Pendidikan Universitas Jember Tahun Akademik 2014/2015.

[11] Widodo, P. P., Handayanto, R. T., \& Herlawati. (2013). Penerapan Data Mining dengan Mathlab. 